AGRICULTURE AND BIOLOGY JOURNAL OF NORTH AMERICA

ISSN Print: 2151-7517, ISSN Online: 2151-7525, doi:10.5251/abjna.2013.4.3.205.215

(C) 2013, ScienceHuß, http://www.scihub.org/ABJNA

\title{
Formulation and production of multinutrient blocks for ruminants in the guinea savanna region of nigeria
}

\author{
${ }^{1}$ A. A. MUBI, ${ }^{2}$ A KIBON AND ${ }^{2}$ I. D. MOHAMMED \\ ${ }^{1}$ Department of Animal Production, Adamawa State University, PMB 25 Mubi, Adamawa \\ State Nigeria. \\ ${ }^{2}$ Department of Animal Science, University of Maiduguri PMB 1025 Maiduguri, Borno \\ State Nigeria
}

\begin{abstract}
A study on the production and utilization of multinutrient blocks using locally available feed resources was conducted at the Adamawa State University, Livestock Teaching and Research Farm Mubi. The cost of production hardness and compactness and utilization were evaluated as feed supplement to cattle and sheep during the dry and wet seasons. Two multinutrient blocks were developed using local ingredients, multinutrient blocks with molasses (MNBM) and multinutrient blocks without molasses (MNBW). The chemical compositions of MNBM were DM $(94.5 \%)$, CP (12\%), CF (16\%), EE (8.5\%), Ash (9\%) and NFE (54.5\%). The MNBW contains DM (95.4\%), CP (13.5\%), CF (18.0\%), EE (6.5\%), Ash (6\%) and NFE (56\%). The hardness at 15/30 days after moulding was $3.6 \mathrm{~kg} / \mathrm{cm}^{2}, 3.8 \mathrm{~kg} / \mathrm{cm}^{2} ; 3.9 \mathrm{~kg} / \mathrm{cm}^{2}$ and $4.1 \mathrm{~kg} / \mathrm{cm}^{2}$ for MNBM and MNBW while the compactness was good both for MNBM and MNBW. The cost of production of a block of $2 \mathrm{~kg}$ weight was N43.66 and $\mathrm{N} 30.15$ for MNBM and MNBW respectively.
\end{abstract}

\section{KeyWords: Multinutrients block, Formulation, Ruminants}

\section{INTRODUCTION}

Ruminant animals play a significant role in the rural economy of Nigeria. With their inherent qualities thriving under harsh environments and low capital investment by the rural farmer under the free range systems, ruminants act as an insurance against crop failures and provide alternative sources of livelihood to the farmers all year round (Selvam and Safiullah, 2002). These animals mostly thrive on grazing of natural grasses, crop residues as well as browsing on shrubs and tree leaves.

The major cereal crop residues in the northern guinea savanna zone of Nigeria are maize, sorghum stovers, rice straws and chaffs. These constitute the bulk of ruminant livestock feed in the dry season. The low nitrogen and mineral contents of the stovers as well as their high lignin and silica contents are considered the major reason for their low digestibility and consequently low productivity of the animals (Verma and Jackson, 1984; Van Soest, 1992; Sundsol et al.,1999; Smith et al., 2005).

These feed resources are characterized by low digestibility, energy, crude protein and poor availability of minerals and vitamins (Prasad et al., 2001; Nagpal and Arora, 2002). Efforts to improve the intake of these poor quality crop residues through supplementation with conventional concentrate feeds of both plant and animal origin which are rich in protein, have been marginal due to their high cost and demand for use in human food and feeding of non-ruminant livestock (Singh et al.,2001).

The main objective of this study is to evaluate various formulations of multinutrient blocks as supplements for ruminant feeding under the semi-intensive and intensive system of management. The specific objectives are to:

i) formulate multinutrient blocks using locally available feed resources;

ii) Evaluate the hardness and compactness of the multinutrient blocks for cattle and sheep.

iii) Evaluate the cost analysis of multinutrient blocks as feed supplement to ruminants. 


\section{MATERIALS AND METHODS}

Study Area: The experiment was conducted at the Livestock Teaching and Research Farm of Adamawa State University, Mubi, Nigeria. Mubi is situated in the Northern Guinea Savanna zone of Nigeria at latitude $11^{0 \mathrm{E}}$ and longitude $13^{\circ} \mathrm{N}$, and $969 \mathrm{~m}$ above the sea level (Andrawus and Yusuf, 2001).

The location of Mubi is generally higher compared with other parts of Adamawa State. The elevation ranged from $400-1500 \mathrm{~m}$. The high land mountain ranges from $1200-1500 \mathrm{~m}$; the high plains elevation ranges between $400-800 \mathrm{~m}$ and occupy about $40 \%$ of the area (Tukur, 1999). The temperature is slightly cool between November and February, and there is a gradual increase in the temperature from January. Monthly mean temperatures range from 16 to $27^{\circ} \mathrm{C}$ (Andrawus and Yusuf, 2001). The seasonal pattern of relative humidity is low between January to March. It rises in April and reaches a maximum in August (55$80 \%$ ). The relative humidity decreases as from October following cessation of rainfall (Adebayo, 2004). Monthly rainfall increases from May to August, while it decreases from September to October, the annual rainfall ranged from 1000 to $1050 \mathrm{~mm}$ (Andrawus and Yusuf, 2001)

Livestock production is predominantly extensive rather than intensive, using range land, crop residues and collected fodder to a greater extent than sown pastures and concentrates. Livestock production is a business activity to the people of this region, except for the few nomadic cattle rearers that move their herds in and out of the area depending on the season. Large varieties of animals are kept; the major ones are cattle, sheep, goats, poultry and pigs (Gadiga, 2004).

Sources of raw materials: The principal ingredients used for the manufacture of the multinutrient blocks are:

1. Molaasses 2. Urea 3. Cottonseed cake 4. Sorghum brewers' dried grains 5. Salt 6 . Maize offal 7. Cement

(i) Molasses is obtained from savanna sugar company; Numan;. (ii) Urea from the Adamawa State Agricultural Development Project; (iii) Cotton seed cake from AFFCOT oil mill in Ngurore, Yola;
(iv)Sorghum brewers dried grains from local beer brewers in Mubi; and (v) Cement and Salt from accredited Dangote Dealers in Mubi Central Market.

Production of multinutrient blocks: The cold process was used for the production of multinutrient blocks which does not require sophisticated equipment such as a double-jacket boiler nor much energy (no heating). The blocks were made by hand (manually) in batches. The mixing procedures involved weighing appropriately each of the ingredients in the following order, from the mineral first, followed by binders diluted in water except molasses then the protein sources and finally the energy sources. All lumps were broken to ensure proper mixing and to avoid toxicity problems when fed to animals. Additional water was added into a 20litre capacity bowl followed by a simultaneous addition of urea and salt of known (quantities) to completely dissolve for about 20 minutes.

Cement was added to the mixture and stirred for 5 minutes to blend and stirred properly with a strong stick for 10 minutes to obtain a homogeneous mix after which the whole mixture was transferred into a half drum so as to have enough room to contain the energy sources as they were added. The remaining water which was previously used to dilute some ingredients was added to the mixture and properly mixed to attain a homogeneous mix; the total mixture was made up to $100 \mathrm{~kg}$ each for multinutrient blocks with molasses and multinutrient blocks without molasses. Each product was carefully placed in moulds, compressed and left in a well-ventilated room to set. The composition of the ingredients of the multinutrient blocks is shown in Table 1

Moulding and drying of multinutrient blocks: The mixed material was placed into a $15 \mathrm{~cm} \times 15 \mathrm{~cm} \times 10 \mathrm{~cm}$ $(\mathrm{L} \times \mathrm{W} \times \mathrm{H})$ Wooden mould. The mould was lined with plastic sheeting to prevent the block from sticking to the walls and to allow easy removal from the moulds. Water was smeared on the inside plastic liner of the mould for easy removal of the cast blocks. The moulds were removed from the blocks after setting and were air dried in the open air under a shade for 30 days. 
Table 1. Compositions of the ingredients used in the multinutrient blocks.

\begin{tabular}{|l|c|c|}
\hline Ingredients (\%) & MNBM & MNBW \\
\hline Energy source: & 25.00 & 00.00 \\
\hline Molasses & 30.00 & 30.00 \\
\hline Brewer`s dried grains & 00.00 & 25.00 \\
\hline Maize offal & & 25.00 \\
\hline Protein source: & 23.00 & 05.00 \\
\hline Cottonseed cake & 05.00 & 05.00 \\
\hline Urea & & 10.00 \\
\hline Mineral source: & 12.00 & $\mathbf{1 0 0 . 0 0}$ \\
\hline Mineral salt (NaCl) & $\mathbf{1 0 0 . 0 0}$ & \\
\hline Binder: & & \\
\hline Cement & & \\
\hline Total & & \\
\hline
\end{tabular}

\section{Key}

MNBM $=$ Multinutrient blocks with molasses

MNBW $=$ Multinutrient blocks without molasses

Drying and packaging of the blocks: The blocks were completely dry after 30 days. After drying the blocks were packaged individually by wrapping them in polythene sacks and kept in a safe storage area not too humid and well-ventilated under room temperature.

\section{Measurements}

Hardness: The measurement for hardness was done using a penetrometer, one of the Chattilon precision instruments (Chattillon -N.Y.-USA. GAUGE R.-CATL 719-20). For every block the relative force needed to sink the penetrometer to a preset depth was determined.

Compactness: Compactness was tested by three persons independently using the Hassoun (1989) method. The blocks are graded as null, moderate, fairly good or good

Physical characteristics: Colour, taste, texture and smell/aroma was determined independently by three persons according to Hadjipanayiotou (1994) methods.
Chemical analysis: All the ingredients and the two formulated experimental blocks were analysed for dry matter, crude protein, crude fibre, ether extracts, ash and nitrogen free extracts using the methods of the Association of Official Analytical Chemists (A O A C, 2000)

Cost analysis of blocks production: The cost of block production for the two formulations was calculated based on the current prices of the ingredients at the time of production.

\section{RESULTS AND DISCUSSION}

Multinutrient blocks formulation: Two formulations manufactured are shown in Table 3.1 The MNBM had $25 \%$ molasses, brewers' dried grains (30\%), maize offal $(0 \%), 23 \%$ cottonseed cake, mineral salt $(5 \%)$, urea $(5 \%)$ and $12 \%$ cement. The MNBW contains molasses (0\%), brewers dried grains (30\%), maize offal $25 \%$, cottonseed cake $25 \%$, salt $(5 \%)$, urea $(5 \%)$ and $10 \%$ cement as a binding agent. Hadjipanoyiotou (1996), Sansoucy, (1986) and 
Hassoun and $\mathrm{Ba}$ (1991) reported an inclusion of molasses in multinutrient blocks ranging from $24.5 \%$ to $25 \%$; this is within the range of the present study.

Some workers (Sansoucy 2007; Bheekhee 2006; Samad and Siddiki, 2004; FFTC 2006; Mwenda and Khasatsini 2008)) used molasses in formulations of multinutrient blocks with molasses which ranged from 28 to $50 \%$ and was higher than the values in this study. Samanta et al., (2003) reported a 10\% inclusion of molasses which is lower than $25 \%$ used in this work. The brewers ' dried grains used in this study are similar to the $30 \%$ inclusion by FAO (1995) but are lower than the $50 \%$ used by Hadjipanayioutou (1976) in formulations of multinutrient blocks with or without molasses with variety of binders.

The maize offal is within the range of $24.5 \%$ reported by (Onwuka, 1993) but slightly higher than the $20 \%$ reported by Hassuon (1989). The cotton seed cake is higher than the $15 \%$ reported by Mohammed et al. (2007). The urea level in this study was slightly lower than the $10 \%$ and $8 \%$ reported by FFTC (2006). The salt levels used in the manufacture of the blocks are within the range of $5 \%$ reported by Mohammed et al. (2007) and Waruiru, (2004) but higher levels (10\%) were reported by Samanta et al. (2003).

The cement levels of the two formulations of MNBM and MNBW were lower than the $17 \%$ reported by Bheekhee $(2002 ; 2006)$ but within the range of 10 to $15 \%$ reported by Hadjipanayiotou (1996). Cement at $10 \%$ and $12 \%$ serves as a good binder in this study; it also gave a good compactness and hardness to the blocks. The order of the mixing technique also gave good compactness and hardness. However, the proportion of feeds ingredients used in this study was similar to those used by Salman (2007); Forsberge (2002); Arias et al. (2002); and Rafiq et al. (2004). The production of multinutrient blocks was promoted by Food and Agriculture Organization intervention in different parts of the world (Hassoun, 1989; Hadjipanayiotou et al., 1993a, b) as a feed supplement to ruminants.

Hardness and compactness of the multinutrient blocks: The results of the measurement of hardness and compactness of the blocks are presented in Table 2. At 15 and 30 days after moulding the hardness was $3.6 \mathrm{~kg} / \mathrm{cm}^{2}$ and $3.8 \mathrm{~kg} / \mathrm{cm}^{2} ; 3.9 \mathrm{~kg} / \mathrm{cm}^{2}$ and $4.1 \mathrm{~kg} / \mathrm{cm}^{2}$ respectively for multinutrient blocks with molasses, and multinutrient blocks without molasses while the compactness was good both for MNBM and MNBW respectively.

The study showed that hardness increased progressively with an increase in time. This is in line with the findings of Sansoucy (1986) who stated that with cement as a binder, hardening time was much longer and it increases with time. The drying period in this study was 15 and 30 days and is contrary to the report of Mohammed et al. (2007) who recorded a drying period of 7days after compounding and this difference may be due to climatic conditions during production. Similarly Hassoun (1989) reported hardness and compactness after four (4) days of formulations.

Table 2. Hardness and compactness of multinutrient blocks $15 / 30$ days after moulding

\begin{tabular}{|c|c|c|c|c|}
\hline Parameter & \multicolumn{4}{|c|}{ Days after moulding } \\
\hline & \multicolumn{2}{|c|}{15} & \multicolumn{2}{|r|}{30} \\
\hline Hardness (H+) & MNBM & MNBW & MNBM & MNBW \\
\hline \multicolumn{5}{|l|}{ Penetrometer } \\
\hline $\begin{array}{l}\text { Technique } \\
\text { Compactness (C) }\end{array}$ & $3.6 \mathrm{~kg} / \mathrm{cm}^{2}$ & $3.8 \mathrm{~kg} / \mathrm{cm}^{2}$ & $3.9 \mathrm{~kg} / \mathrm{cm}^{2}$ & $4.1 \mathrm{~kg} / \mathrm{cm}^{2}$ \\
\hline Hassoun Technique & Good & Good & Good & Good \\
\hline
\end{tabular}

KEY

MMBM $=$ Formulated multinutrient blocks with molasses

MNBW = Formulated multinutrient block without molasses 
More so, Sansoucy et al. (1988) and Hassoun (1989) also reported that the desired hardness is reached in 47 days after manufacturing which is not consistent with this finding. Preston (1993) reported that drying for more than 30 days of blocks with cement may cause problem of block cohesion.

Hadjipanayioutou (1996) reported that blocks containing molasses were softer than the ones without molasses. However, the hardness increases with an increasing level of the binding agent and time of storage. The inclusion of brewers dried grains and maize offal affects compactness due to its moisture retention capacity (Hadjipanayioutou et al., 1993b). This study showed that the desirable hardness and compactness was achieved 30 days after manufacture of the blocks. This may be due to high moisture retention by the brewers dried grains and maize offal but incorporating them improved the blocks quality.

The level of cement at 10 and $12 \%$ as a binder gave a good level of compactness and hardness, the higher levels in this work was probably due to incorporation of brewers 'dried grains and maize offal as ingredients in the blocks formulations and is within the safety limits.

Similar levels of cement ranging from 10 to $15 \%$ were used by Hadjipanayiotou (1996). Levels of 11.37 and $12.24 \%$ for blocks with or without molasses was also reported by Hinojosa et al. (2000) but slightly higher than the level of $10 \%$ reported by Hadjipanayioutou et al. (1993a) Sansoucy (2007) also recommended the inclusion of $15 \%$ cement as a binding agent. It has also been reported (Sansoucy et al., 1988; Hadjipanayioutou et al., 1993a) that long storage of some formulations result in extremely hard blocks that could reduce block intake.

It is preferable that blocks are made at a time prior to their use so that they could reach the desired degree of hardness at the time required. Ma et al. (1992) and Hadjipanayioutou (1996) reported that, when long storage period is inevitable, wrapping or storing the blocks in polyethylene sheets/bags will maintain the desired hardness; these blocks were produced by cold process.

Physical characteristics of multinutrient blocks: The multinutrient blocks with molasses displayed a very dark brown colour after 15/30 days drying period, and this could be as a result of the presence of molasses $(25 \%)$ as an ingredient in the blocks (Sansoucy, 2007).

The multinutrient blocks without molasses was light brown in colour. This could be due to the presence of cottonseed cake, maize offal and brewers dried grains and absence of molasses.

The multinutrient blocks with molasses have a good aroma and taste sugary due to the presence of molasses, while the smell of multinutrient blocks without molasses is slightly acidic and dull but is salty due to salt and urea combined in the blocks as reported by Hadjipanayiotou (1996).

The texture of multinutrient blocks without molasses is smoother due to the oily nature of molasses in the blocks while coarser in multinutrient blocks without molasses and this may be as a result of the ingredients used to manufacture the blocks (Hassoun, 1989).

The chemical composition of the basal diet and multinutrient supplement blocks : The results of the chemical composition of the basal diet and multinutrient supplement blocks are presented in Table 3. The rice straw has $97.0 \%$ dry matter, $5.4 \%$ crude protein, $26.05 \%$ crude fibre, ether extract $4.05 \%$, total ash $16.5 \%$ and $48.0 \%$ nitrogen free extracts. The dry matter content of rice straw is within the range (96 to $98 \%$ ) reported by other authors (Jayasuriya 1979; Menge et al., 1993; Chuzaemi 1994). The values in this work are higher than the 93.7\% reported by Adebowale (1993) and Wanapat (2004). The crude protein is within the range of 5 to 6\% reported by (Shi et al., 1997; Liu et al., 1998 and Liu et al., 2000). 
Agric. Biol. J. N. Am., 2013, 4(3):205-215

Table 3. chemical composition of the basal diet (rice straw) and multi-nutreint blocks

\begin{tabular}{|l|c|c|c|}
\hline \multirow{2}{*}{ Feed ingredient } & \multicolumn{3}{|c|}{ Diet Composition (\%) } \\
\cline { 2 - 4 } & RICE STRAW & MNBM & MNBW \\
\hline Dry matter & 97.0 & 94.5 & 95.4 \\
\hline Crude protein & 5.4 & 12.0 & 13.5 \\
\hline Crude fibre & 26.05 & 16.0 & 18.0 \\
\hline Ether Extract & 4.05 & 8.5 & 6.5 \\
\hline Total Ash & 16.5 & 9.0 & 6.0 \\
\hline Nitrogen-Free Extract & 48.0 & 54.5 & 56.0 \\
\hline
\end{tabular}

KEY

MNBM $=$ Multinutrient blocks with molasses

MNBW = Multinutrient block without molasses

Other workers (Alhassan et al., 1987) Kusmartono (2001) and Wanapat et al. (2004) reported lower values of crude protein.

The crude fibre content was within the range of 26.2 to $26.5 \%$ reported by (Seijas et al., 1994; Chuzaemi 1994; Yuangklang et al., 2001). The ash content is similar to 16 to $17 \%$ reported by Seijas et al. (1994) and Yuangklang et al. (2001). The variations may be due to varietal difference, soil type and possibly fertilizer application (Vatta el al., 2004).

The proximate analyses of the MNBM are $94.5 \% \mathrm{DM}$, $12.0 \% \mathrm{CP}, 16.0 \% \mathrm{CF}, 8.5 \% \mathrm{EE}, 9.0 \%$ total ash and $54.5 \%$ NFE; While MNBW had $95.4 \%$ DM, $13.5 \%$ $\mathrm{CP}$, and $18.0 \% \mathrm{CF}, 6.5 \% \mathrm{EE}, 6.0 \%$ total ash and $56 \%$ NFE. The differences in the chemical composition of the blocks

may be due to differences in the ingredients used in the manufacture of the multinutrient blocks. The high dry matter percent obtained is an indication that the blocks were properly dried for 30 days. Avilla (1995) reported a similar DM\% of 94 to $97 \%$ DM of multinutrient blocks formulated with or without molasses in the dry and wet season. Lower values of 45 to $50 \%$ DM were reported by Smith (2002) and Chowdhury and Huque (2008).

The crude protein obtained was 12.0 and $13.5 \%$ for MNBM and MNBW respectively. The results are similar to those of Sansoucy et al. (1986) Garg et al. (1993); Aung et al. (2008); Chowdhury and Huque (2008. The ingredients used are similar to those used

by Hadjipanayioutou (1996) in block formulations with a variety of binders with or without molasses.

The crude fibre content was 16.0 and $18.0 \%$ for MNBM and MNBW respectively and is within the range reported by Smith et al. (2005) but lower than the $10 \%$ by Bhehkhee (2006) and higher than $12 \%$ reported by Mohammed et al. (2007) and Onwuka (1993).

The total ash content were 9.0 and $7.0 \%$ in MNBM and MNBW respectively and lower than 24\% reported by Avilla (1995). The nitrogen free extract was 54.5 and $56.0 \%$ for MNBM and MNBW respectively. These values were similar to Chowdhury and Huque (2008) but dissimilar to Hassoun (1989) who reported $60.2 \%$.

Chemical composition of feed ingredients: Table 4. shows the proximate analysis of ingredients used for the formulation of multinutrient blocks. The dry matter ranged from $70-97 \%$ for all the ingredients used in the formulations.

The highest DM content recorded was (96\%) in maize offal and the lowest DM was in molasses $(70 \%)$ and the results are similar to those of Hussaini (1998), Onwuka (1993) and Gadzama (2008).

The DM in brewers' dried grains was slightly higher than $90.5 \%$ reported by Hadjipanayioutou (1996), $83.67 \%$ by Ramchurn and Raggoo (2000) and $90.02 \%$ reported by Lanya sun ya (2006).

The crude protein content ranged from 3 to $17.30 \%$ in molasses and cottonseed cake respectively; salt and cement had no CP content. The 
CP obtained was similar to those reported by FAO (1988). Maize offal and brewers` dried grains CP was slightly higher than the other ingredients.

Bheekhee (2006) and Mohammed et al. (2007) recorded a lower CP of 2.50 and $2.80 \%$ respectively for molasses. Bunderberg (2008) and Waruiru (2004) recorded a higher value of 4.5 and $4.37 \%$ in molasses respectively. Ether extract of the ingredients ranged from 0.45 to $7.35 \%$ in molasses and maize offal respectively.

The value of ether extract in maize offal is similar to the values of $7.35 \%$ reported by Mohammed et al. (2007) and is in contrast to $8.37 \%$ reported by Hadjipanayoutou et al. (1993a, b), Hussaini (1998) and Gadzama (2008).

Table 4. Chemical composition of feed ingredients.

\begin{tabular}{|c|c|c|c|c|c|c|c|}
\hline \multirow{2}{*}{$\begin{array}{l}\text { Feeds } \\
\text { Constituents }\end{array}$} & \multicolumn{7}{|c|}{ Chemical composition (\%) } \\
\hline & $\mathrm{MO}$ & BDG & CSC & MLSES & UREA & SALT & CMT \\
\hline $\begin{array}{l}\text { Dry matter } \\
\text { (DM }\end{array}$ & 96.00 & 93.27 & 95.00 & 70.00 & - & - & - \\
\hline $\begin{array}{l}\text { Crude } \\
\text { Protein }(C P)\end{array}$ & 12.14 & 15.00 & 17.30 & 3.00 & - & - & - \\
\hline $\begin{array}{l}\text { Crude Fibre } \\
\text { (CF) }\end{array}$ & 13.50 & 12.02 & 13.80 & 0.00 & - & - & - \\
\hline $\begin{array}{l}\text { Ether Extract } \\
\text { (EE) }\end{array}$ & 7.35 & 5.80 & 7.05 & 0.45 & - & - & - \\
\hline Ash & 4.05 & 5.01 & 4.08 & 4.78 & - & - & - \\
\hline NFE & 62.96 & 62.17 & 57.77 & 91.77 & - & - & - \\
\hline $\begin{array}{l}\text { Calcium } \\
\text { (ppm) }\end{array}$ & 0.30 & 0.41 & 0.17 & 0.65 & & & - \\
\hline $\begin{array}{l}\text { Sodium } \\
\text { (ppm }\end{array}$ & - & - & - & - & - & 30.0 & - \\
\hline $\begin{array}{l}\text { Chlorine } \\
\text { (ppm) }\end{array}$ & - & - & - & - & - & 70.1 & - \\
\hline Nitrogen & - & - & - & - & 4.53 & - & - \\
\hline Iron & - & - & - & - & - & - & 22.55 \\
\hline $\begin{array}{l}\text { Menganese } \\
(\mathrm{ppm})\end{array}$ & - & - & - & - & - & - & 180.33 \\
\hline $\begin{array}{l}\text { Magnesium } \\
\text { (ppm) }\end{array}$ & - & - & - & - & - & - & 139.23 \\
\hline $\begin{array}{l}\text { Phosphorus } \\
\text { (ppm) }\end{array}$ & 0.20 & 0.01 & 1.20 & - & - & - & - \\
\hline
\end{tabular}

KEY

NFE = Nitrogen-free extract

$\mathrm{MO}=$ Maize offal

$\mathrm{BDG}=$ Brewers `dried grain

CSC $=$ Cottonseed cake

MLSES = Molasses

CMT $=$ Cement 
Agric. Biol. J. N. Am., 2013, 4(3):205-215

The crude fibre ranged from 0.00 to $13.80 \%$ for all the ingredients. The highest CF content (13.80\%) was found in cottonseed cake. Brewers dried grains had the lowest $(12.02 \%)$ crude fibre. The values were similar to $12 \%$ in Bunderberg (2008). The ash content ranged from 4.05 to $5.01 \%$ in maize offal and brewers dried grains. These values were incontrast to the values reported by Onwuka (1993).

The Nitrogen free extract values ranged from 57.77 to $91.77 \%$ in cotton seed cake and molasses respectively the mineral contents of the ingredients varies, the calcium level obtained ranged from 0.03 to $0.65 \mathrm{ppm}$ in all the ingredients. The salt contains $30.0 \mathrm{ppm}$ sodium and $70.01 \mathrm{ppm}$ chlorine. Iron and magnesium are about 22.55ppm and 180.33ppm in cement.

Nitrogen in urea was $4.53 \mathrm{~g}$ and the figure was similar to Preston (1993) who reported $4.50 \mathrm{~g}$. Kayouli (1994b) reported also a lower value of 3.35. The magnesium in cement is about 139.23ppm. Phosphorus ranged from 0.01 to 1.20 ppm in brewers dried grain and cottonseed cake

Cost of production of multinutrient blocks:Table 5. shows the cost of ingredients used in formulating the multinutrient blocks; $100 \mathrm{~kg}$ of ingredients cost about N3318.18 and N2291.50 for MNBM and MNBW respectively.

The cost of producing blocks with molasses is higher than those without molasses, due to the high cost of molasses. A unit of $2 \mathrm{~kg}$ blocks costs about $N 43.66$ and $\mathrm{N} 30.15$ for MNBM and MNBW respectively

Table 5. Cost of production of multinutrient blocks

\begin{tabular}{|l|c|c|}
\hline \multirow{2}{*}{$\begin{array}{l}\text { Feed } \\
\text { Ingredients }\end{array}$} & \multicolumn{2}{|c|}{ Multinutrient Block cost (N) } \\
\cline { 2 - 3 } & MNBM & MNBW \\
\hline Molasses & 1500.00 & 00.0 \\
\hline $\begin{array}{l}\text { Brewers`Dried } \\
\text { Grains }\end{array}$ & 600.00 & 600.00 \\
\hline Maize Offal & 00.0 & 500.00 \\
\hline $\begin{array}{l}\text { CottonSeed } \\
\text { Cake }\end{array}$ & 383.18 & 416.50 \\
\hline Salt & 120.00 & 120.00 \\
\hline Urea & 355.00 & 355.00 \\
\hline Cement & 360.00 & 300.00 \\
\hline Total & $\mathbf{3 3 1 8 . 1 8}$ & $\mathbf{2 2 9 1 . 5}$ \\
\hline Cost/Block (N) & $\mathbf{4 3 . 6 6}$ & $\mathbf{3 0 . 1 5}$ \\
\hline
\end{tabular}

KEY

MNBM = Multinutrient blocks with molasses

MNBW $=$ Multinutrient block without molasses

\section{CONCLUSION}

The manufacture of blocks with or without molasses has been undertaken. The practicability of the cold process has been demonstrated. The technology of making multinutrient blocks for dry and wet season feeding is both simple and practicable and does not need sophisticated equipment

\section{REFRENCES}

Adebayo, A.A. (2004). Mubi Region. A Geographical Synthesis $1^{\text {st }}$ Edition, Paraclete Publishers, Yola, Nigeria, Pp 32-37

Adebowale, E. A., Taiwo, A. A. ,and Greenhalgh, J. F. D.(1993) Goats Production System In The Tropics (Ayeni and Bosman Eds) Pudoc. Wageningen, The Netherlands. Pp187-194.

Andrawus, A.U. and Yusufu, W.H. (2001). Effects of Dates of Sowing on Growth and Yield of Soybeans in The Northern Guinea Savanna Environment of Nigeria. Sabondale Journal of Technical Education 4: 82-87

A. O. A. C. (2000). Official Methods of Analysis. $17^{\text {th }}$ Ed. Association of Official of Analytical Chemists, Gaithersburg. MD Germany.

Arias, L., Lopez, M., Losada, H., Cortes, J., Soriano, R. and Grande, D. (2002). A Note on the effects of molasses/Urea lick blocks on milk production of dairy cows maintained in the Urban Environment of Iztapalapa, Mexico, City: A case Study. Livestock Research for Rural Development 14 (6): 20-25

Aung M, Ye, Y. W. and Thun, T. (2008). Effects of Multinutrient Blocks on Cross-Bred Friesian Calves. Final Research Coordinating Meeting of FAO/IAEA Coop Swedish University of Agricultural Science Uppsala, Sweden 10-14 May, 2008.

Avilla, H. F. (1995). Production and Utilization of UreaMolasses Blocks/mineral blocks in the Philippines. FAO-APHCA. Asian Livestock 18 : 199-204.

Bheekhee,H. (2006). Urea-Molasses Multinutrient Blocks (UMMB) As a Feed Supplement for Ruminants. Agricultural Research and Extension Unit.Curepipe Livestock Research Station, Mauritius

Bheekhee, H., Holman, B., Boodoo, A. A., Ramnauth, R. K, Yuen, R. L.H, Fakim, R. and Dobee B (2002). Development and Field Evaluation of Animals Feed Supplementation Packages for Improving Meat and Milk Production in Ruminant Livestock Using Locally Available Feed Resources. Proceedings of the Final Review Meeting of an IAEA Technical Cooperation Regional AFRA Project IAEA-TeCDOC-1294.

Bundaberg (2008): Molasses. Australian Stock Feed Industry http:www.bundy sugar.com.au/molasses/molasses/htm/. June,2008 
Chowdhury, S.A., and Huque, K.S. (2008). Feeding Urea and Molasses on a Straw Diet: Urea-Molasses Straw. Animal Production Research Division, Bangladesh Livestock Research Institute, Savar, Dhaka, Bangladesh http//www.fao.org/AG/AGAinfo/resources.May, 2008.

Chuzaemi, S. (1994). Potensi jerami padi Sebagai Pakan Ternak Ditinjau dari Kinetika Degradasi dan Retensi Jerami Didalam Rumen. Disertasi University Gadjah Mada. Yogyakarta.

FAO (1995) World Animal Review for Better Farming Series 45, Multinutrient Handbook, Pp28, FAO, Rome, Italy.

FAO/UNESCO (1988). Soil Maps of the World. Revised Legend. World soils Resources Report 60. FAO, Rome.

FFTC (2006). Food And Fertilizer Technology Centre; Urea Molasses Mineral Block Supplement For Ruminants: Philippines Council For Agric. and Natural Research and Development (PCARRD), Los Banus, Laguna, 4030, The Philippines.

Forsberg, N. E., Al-Magbaly, R., Al-Halhali, A., Ritchie, A. and Asrikandakumar, A. (2002). Assessment of Molasses-Urea Blocks for Goat and Sheep Production in the Sultanate of Oman: Intake and growth studies.Journal of Tropical Animal Health and Production 34: 231-239

Gadiga, B.L. (2004). Livestock Production. In: Mubi Region. A Geographical synthesis, $1^{\text {st }}$ Edition, Paraclete Publishers, Yola, Nigeria. A. A. Adebayo (Eds) Pp 64-68

Gadzama, I U. (2008) Dusa-rice Bran Multinutrient Blocks in a Semi-arid Environment of North East Nigeria. Department of Animal Science, University of Maiduguri, Maiduguri, Borno State, Nigeria.

Hadjipanayioutou, M. (1994). Voluntary Intake and Performance of Ruminant Animals Offered Poultry Litter Silage. Livestock for Rural Development 6 (2): $24(\mathrm{~Kb})$

Hadjipanayiotou, M. (1996) Performance of Friesian Heifers On Urea Blocks and of Chios Ewes On Blocks and Other Supplements. Livestock Research for Rural Development 8 (4): 1-8

Hadjipanayiotou, M. (1996). Urea Blocks Made Of a Variety Of By-products and Binders. Livestock Research for Rural Development, 8 (5): 16-18.

Hadjipanayiotou, M., Verhaeghe L., Aleen M., Kroufoleh A.R., L.M. labban, A. Shurbaji, M. Al-Wadi, M. Dassonki, B. Shenkar and M. Amin (1993a). Urea Block 1. Methodology of Block Making Of Different Formulae Tested in Syria. Livestock Resources For Rural Development 5 (3) : 6-15

Hadjipanayiotou M., Verhaeghe, L., Allen, M., Kronfoleh, A. R., Labban, L. M., Amin, M., Alwali, M., Badran, A.,
Dawa, K., Shurbaji, A., Houssein, M., Maliki, G., Naigmi, T., Merawi, A.R. and Harres, A. K. (1993b). Urea Block II. Performance Of Cattle And Sheep Offered Urea. Livestock Research for Rural Devevelopment 5 (3): 1-4

Hassoun, P. (1989). Manufacture Of Urea Blocks Without Molasses. A Monograph, FAO, Rome, Italy.

Hassoun, P. and Ba, A. A. (1991). Mise An Point D Une Technique De Fabrication De Blocks Multinutritionnels Sans Melasse. Livestock Research for Rural Development, 2 (2):8-9 .

Hinojosa, O., Stemmer, A and Valle Zarate, A. (2000). Effect of Multinutrient Blocks on growth of Kids at the End of the Dry Season in Bolime. Proceedings of the Seventh International Conference on Goat Production, Paris France Pp 173-174.

Jayasuriya, M.C.N (1979). The utilization of Fibrous Residues in South Asia. Proceeding of Workshop on Bioconversion of Lignocellulusic and Carbohydrate Residues in Rural Communities, December 11-15, Bali, Indonesia.

Kayouli, C. (1994b). Rapport de Mission, Project FAO/PNUD/NER/89/016 Traitement a Luree des fourrages grossier, Niger mai 1994 Pp28.

Lanya sun ya, T.P., Wang, H., Ring, S.A., Abdulrazak, P.K., Raburu, J.O., Onyango, T. A. and Mwangi, D.M. (2006). Factors limiting Use of Poultry Manure as Protein Supplement for Dairy on Smallholder farms in Kenya. International Poultry Science, 5:75-80.

Liu, J.X., Wang, X. Q., Shi, Q.Z., and Ye, H.W. (2000). Nutritional Evaluation of Bamboo Shoot Shell and its Effect as Supplementary Feed on Performance of Heifer Offered Ammoniated Rice Straw Diet. AsianAustralian Journal of Animal Science 13 (10): 13881393.

Ma, Y. Z., Zhen, R. L and Xu, J. Y. (1992). Manufacturing and Evaluations of Molasses-Urea Lick Block. Tianjin Agricultural Sciences, $1: 25-26$.

Meng, Q. X., and Xiong, Y. Q. (1993). Effects of Ammonia Treatment and Concentrate Supplementation on Growth Performance in Wuzhumugin Wethers Receiving Wheat Straw. Acta Vetrinaria et Zootechnica Sinica, 24 (1): 23-28.

Mohammed,I.D.,Baulube, M. and Adeyinka, I. A. (2007). Multinutrient Blocks 1: Formulation and Production under a Semi Arid Environment of Northern East Nigeria. Jounal of Biological Science, 7 (2):389-392

Mwenda, C.W. and Khasatsili, A. (2008). Molasses Energy Blocks for Beef Cattle. National Agricultural Station, Kitale Kenya. http//www.ilri.org/infoserv/webpub/fulldocs.April, 2009

Nagpal, A. K. and Arora, M. (2002). Utilization of Guar Phalgati and Tree Leaves BasedComplete Diets In Camel. Indian Journal of Animal Science, 72: 712-714. 
Onwuka, C.F. (1993). Nutritional Evaluation of Some Nigerian Browse Plants in the Humid Tropics. Ph.D. Thesis, Department of Animal Science., University of Ibadan, Ibadan, Nigeria (cited by Oguntola, 1985)

Prasad, G. S., Gowda, N.K.S. and Ramana, J.V., (2001). Feeding Strategies To Enhance Animal Productivity, In: Proceedings Of The Xth Animal Nutrition Conference, NDRI, Kamal, India, 9-11 ${ }^{\text {th }}$ Nov. 2001. Pp23-45.

Preston, T. R. (1993). Report of The First Advisory Mission. Increasing Livestock Production By Making Better Use Of Available Feed Resources. FAO/TCP/URT/2255 Project. Republic of Tanzania, June $20^{\text {th }}, 1993$. Pp 3454.

Rafiq, K., Mostofa, M. and Saiful, M. (2004). Studies on the Antinematodal Effects of Medicated UreaMolasses mineral Blocks Against Gastrointestinal Nematodiasis in Indigenous Dairy Cows of Bangladesh. Pakistan Journal of Biological Sciences, 7 (1): 73-78.

Ramchurn, R., . and Ruggoo, A. (2000). Digestibility And Growth In The Domestic Rabbit Using Multi- Nutrient Blocks As a Feed Supplement. Livestock Research for Rural Development 12 (1). http://.org.co//rrd12/1/ram121b.htm, October, 2008.

Samad Khan. M. A. and Siddiki, S. R. (2004). Preparation of Urea Molasses Blocks (UMB) and Their Use For Livestock: Small Stock. In: Development, Forage Production And UMB Technology, Project (NRI/DFID). Bangladesh Agricultural University, Mymensingh, Bangladesh. Pp 2202.

Salman, A. D. (2007). The Role of Multinutrient Blocks For Sheep Production in an Integrated Cereal-livestock Farming System in Iraq. IPA Agricultural Research Centre. Baghdad, Iraq.

Samanta, A. K., Singh, K. K., Das, M. M., Maity, S.B and Kundu, S. S. (2003). Effect of Complete Feed Block on Nutrient Utilization and Rumen Fermentation in Baribari Goats. Small Ruminant Research, 48 :95-102

Sansoucy, R. (1986). The Sahel-Manufacture of MolassesUrea Blocks. World Animal Review, 57:39-48.

Sansoucy, R. (2007). New Developments in the Manufacture and Utilization of Multinutrient BlocksShort Communications. http//www.fao.org/DOCREP/v4440Tos.htm December,2008.

Sansoucy, R., Aarts, G. and Preston, T.R. (1988). Molasses-Urea Blocks as Multinutrient Supplement for Ruminants. In: Sugar as Feed, Proceedings of a FAO Experts Consultation Held in Santo Domingo, Dominican Republic \&-11/7/1986). FAO Animal Production and Health Paper No 72 Pp319. Food and Agriculture Organization, Rome, Italy
SAS (2001).Statistical Analysis System, SAS 2001 SAS/STAT Software. Release 8.02. SAS Institute Inc. Cary, NC, USA.

Seijas, J., Blanca, A., Torrealba, H. and Combellas, J. (1994). Influence of Gliricidia sepium, Multinutrient Blocks and Fish Meal on Liveweight Gain and Rumen Fermentation of Growing Cattle in Grazing Conditions. Livestock Research for Rural Development, 6 (1): 1-8

Selvam, S. and Safiullah, A. M., (2002). Status of Small Ruminants in Tamil Nadu. Indian Journal of Animal Science. 72: 695-698.

Singh, K. K., Das , M. M., Samanta, A. K., Kundu, S. S. and Sharma, S.D. (2001). Effects of Grass-Based Complete Diets on Feed Intake and Nutrient Utilization In Crossbred Calves, In : Proceedings of the Xth Animal Nutrition Conference. NDRI, Karnal India, 9$11^{\text {th }}$ November, 2001, Pp9-10.

Smith, T. (2002.) Some Tools to Combat Dry Season Nutritional Stress in Ruminants Under African Conditions. Proceedings of the Final Review Meeting of an IAEA Technical Cooperation Regional AFRA Project IAEA-TECDOC-1294. Australia.

Smith, T., Godfrey, S.H., Buttery, P. J., Sewannyane, E. and Owen, E.(2005). Small Stock In Development. Proceedings of A Workshop On Enhancing The Contribution of Small Livestock To The Livelihoods Of Resource-Poor Communities. Hotel Brorad, Masaka, Uganda, Pp 15-19 $9^{\text {th }}$ November, 2004. Natural Resources International Ltd., Aylesford, Kent, UK., (5) 1.Production Projects Proceedings of Work Shop, February, NRIL/DR\&SS. Harare, Zimbabwe.

Sunstol, F., Coxworth, T. and Mowat, D. N. (1999). Improving the Nutritive Value of Straw and other Low-Quality Forages by Treatment with Ammonia. World Animal Review, 6 :13.

Tukur, A. L. (1999). Land Reforms. In: Adebayo, A. A. and Tukur, A. L (Eds). Adamawa State in Maps, Department of Geography, Federal University of Technology, Yola Pp 14-16

Van Soest, P. J. (1992). Nutritional Ecology Of The Ruminants (A Review). O. and B. Books Incorporation, Corvallis, Oregon, USA.

Vatta, A.F., Harrison, L.J. S., Krecek, R.C. and Pearson, R. A. (2004). Relative Economic Benefits of Strategic Anthelmintic Treatment and Urea-Molasses Block Supplementation of Boer Goats Raised Under Extensive Grazing Conditions At Onderstepoot, Pretoria, South Africa. In: Smith,T., Godfrey,S.H., Butter,Y,P.J.,Ssewannane, E .and Owen., (Eds) (2005) Small Stock in Development. Proceedings of a Workshop on Enhancing the Contribution of Small Livestock to the Livelihoods of Resource in Poor Communities. Hotel Broad, Masaka, Uganda, 15-19 
Nov. 2004. Natural Resources International Institute, Aylesford, Icat, UK.

Verma, M. L. and Jacson, M.G. (1984). Straws. In: Practical Ration For Cattle and Buffaloes With Special Reference For Developing Countries. In: Straw and Other Fibrous By-Products As Feed. F. Sunstol and E. Owen (Eds) Elsevier, Amsterdam, The Netherlands, Pp 414-430

Wanapat, M. (2004) Manipulation of Cassava Cultivation and Utilization to Improve Protein Energy Biomass for Livestock in the Tropics. Asian-Australian Journal of Animal Science, 16 (3): 463-472.
Waruiru, R. M. (2004). The influence of Supplementation with Urea-Molasses Blocks on Weight Gain and Nematode Parasatism of Dairy Calves in Central Kenya, Veterinary Research Communication, 28: 1-2.

Yuangklang, C., Wora-anu, S., Wanapat, M., Nontaso, N. and Wachirapakorn, C. (2001). Effects of Roughage source on Rumen Microbes, Feed intake and Digestibility in Swamp Buffaloes. In: International Workshop on Current Research and Development on Use of Cassava as Animal Feed (Editors: T.R. Preston, B. Ogle and M. Wanapat) Khon Khaen University, Thailand, July 23-24, 2001. http:// www.mekan.org/prockk/yuan.htm.January,2007 